\title{
THE HIBBERT JOURNAL
}

A Quarterly Review of Religion, Theology and Philosophy

Edited by The Rev. L. A. Garrard

List of Contents-October 1960

The Problem of a Philosophical

Theology

Freedom and Immortality

The Rev. B. M. G. Reardon

Allah and Caesar

Professor H. D. Lewts

Some Reflections on Questions of Population

ERnest GeLlner

Low Level Approaches to Aesthetic Problems

Dr. E. A. Wrigley

H. D. WALEY

Annual Subscription, $175.6 d$. post free. Single copies 5 s. net

$A$ free specimen copy of a back number will be sent on request

\section{GEORGE ALLEN \& UNWIN LIMITED}

40 MUSEUM ST, LONDON, WC1

\section{MIND}

A Quarterly Review of Psychology and Philosophy Edited by Prof. GILBERT RYLE

With the Co-operation of Prof. Sir F. C. Bartlett and Prof. C. D. Broad

\section{CONTENTS FOR OCTOBER 1960}

Agents, Critics and Philosophers:

Aristotle and the Sea Battle:

The Philosophical Significance of Modal Logic:

Ayer on Perception:

Grammar and Existence: A Preface to Ontology:

Discussions:

Singular Propositions and "this" as a Quantifier:

Moral Arqument:

Mr. Bradley on the Future:

Worship and God:

Private Language: The Logic of Wittgenstein's Argument:

A Note on Deontic Lozic:

Verification and the Performatory Theory of Truth:

New Books

Notes
MARY MOTHERSILL

COLIN STRANG

GUSTAV BERGMANN

A. PHILLIPS GRIFFITHS

WILFRED SELLARS

LEON GUMAŃSKI JONATHAN BENNETT

R. MONTAGUE

R. L. FRANKLIN

JAMES D. CARNEY

JAN BERG

RICHARD K. SCHEER 


\section{The Philosophy}

\section{of C. D. Broad}

\section{EDITED BY}

\section{P. A. SCHILPP}

The new volume in the series The Library of Living Philosophers is on Professor C. D. Broad. It contains an autobiography, critical articles by twenty-one scholars on various aspects of Professor Broad's philosophy, his reply to these critics, and a complete bibliography compiled by Dr. C. Lewy. 878 pages. f5. Ios. net

\section{CAMBRIDGE}

UNIVERSITY PRESS
Published in the berlis SOVIETICA

Editor: Prof. J. M. Bocheniski Ph.D. EINSTEIN

\section{und die Sowjetphilosophie}

Volume 1: Die Grundagen/Dio macilbs Relativitätstheorie

by S. MÚller-Markus Ph.D.

This work - the result of a threo-year atudy of the pertinent Russian sources - offers the Western philosopher and physicist a picture of Soviet discussion since 1950 on the theory of relativity. In addition, an attempt is mado to offer an interpretation of the basic problems which have arisen from the conflict of modern physics with philosophical materialism.

1960, XVI +481 p., Dfl 43.75 or $87 \frac{1}{2}$ s.

D. Reidel Publishing Company DORDRECHT - HOLLAND

\section{Ockham: Philosophical Writings PHILOTHEUS BOEHNER OFM}

The selection contained in this volume gives a balanced introductory view of Ockham's writings on logic, metaphysics and ethics. Latin and English are printed face to face, and the whole has been edited and translated by Fr. Philotheus Boehner, one of the leading authorities on Franciscan philosophy of the Middle Ages.

Nelson's Philosophical Texts $l x+300$

\section{Practical Reason and Morality}

A Study of Immanuel Kant's Foundations for the Metaphysics of Morals

\section{A. R. C. DUNCAN}

The present author examines afresh and in detail the contents of the Foundations for the Metaphysics of Morals and shows that it is not, as has hitherto been mistakenly assumed, an ethical treatise but is what it claims to be-the foundations for a metaphysics of morals, a critique of practical reason, written by the man who bad already produced the Critique of Pure Reason.

siii +182 
Volume III

\section{R A T I O}

edited in co-operation with

W. Ackermann (Münster), H. B. Acton (London),

A. Church (Princeton), H. Cherniss (Princeton),

G. Henry-Hermann (Bremen), K. R. Popper (London), and J. W. N. Watkins (London)

by

Julius Kraft (Frankfurt a.M.)

A. Gysin:

J. F. THOMSON:

W. J. VeRDENIUS:

S. Simitis:

E. W. F. TomLin:

H. M. Peters:

Reviews:

I. M. BocheNSXI: A Précis of Mathematical Logic (W. Ackermann)

F. HeingmanN: From "Die Philosophie im XX. Jahrhundert" (W. Ackermann)

E. Gellner: Words and Things. An Examination, and an Attack upon, Linguistic Philosophy (J. W. N. Watkins)

D. SCHRÖDINGRR: Geist und Materie der Wissenschaft (K. Doehmann)

Price 15s. net - Annual Subscription: 27s. 6d. net
The Origins of the Contract What Achilles should have said about the Tortoise Participation and Contemplation in Ancient Greek and in Modern Thought

The Problem of Legal Logic Mr. Hare's Paper-A Rejoinder Sociomorphic Models in Biology

\section{THE AUSTRALASIAN JOURNAL OF PHILOSOPHY}

CONTENTS FOR AUGUST, 1960

ARTICLES:

NoRwOOD Russell HANSON: Is

There a Logic of Scientific Discovery?

P. C. GibBons: Imperatives and Indicatives (I).

A. R. WALKER: Observations on the Distribution and "Significance" of Terms in Propositions.

RICHARD TAYLOR: Pure Becoming.

George Overend: Confusions in Contemporary Linguistics. DISCUSSION:

Sensations and Brain-Processes: $\mathbf{A}$ Reply to Professor Smart: I.George Pitcher;II.-W.D. Joske.

M. ARThadeva: Mirror Images are Physical Objects: A Reply to Mr. Armstrong.

CRITICAL NOTICES:

John AnDERson: Caponigri's Time and Idea.

D. STOVE: Popper's Logic of Scientific Discovery.

Reviews, BOOKs Received, Notes AND NEWS.

\section{HEFFER'S}

$1 x+\frac{1}{1}+2$

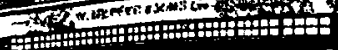

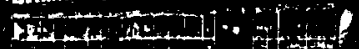

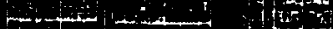

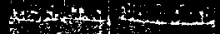

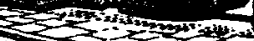

A CAMBRIDGE BOOKSHOP

THAT IS KNOWN

IN ALL PARTS

OF THE WORLD

W. HEFFER \& SONS LTD

Petty Cury, Gambridge 


\section{The Use of Reason}

\section{E. R. EMMET M.A.}

A study of the handling of words and sentences, and the principles of valid reasoning.

'.. an excellent introduction to the use of reason . . . highly recommended for Sixth Form study.' The A.M.A. Fournal

¿... the great value of the book is that it approaches logic gently through a discussion of the familiar use of words and this theme recurs throughout ... The author dwells much on induction and the scientific method, and these chapters at least should be compulsory reading for all those beginning to specialize in science. . . Mr. Emmet cannot be praised too highly for the exercises he has attached to each chapter.... used as the author intended, these exercises make the book into a complete course for self-instruction.

Another outstanding feature is the dry humour which enlivens even the most technical parts and should help to make many rules memorable.'

Price ros. 6d. net

Times Educational Supplement

\section{LONGMANS}

\section{HYPOCRISY AND HUMOUR}

E. J. OLIVER

15/- net

British "hypocrisy" is a world legend. In a splendid survey ranging from Aesop to Orwell, Mr. Oliver shows how hypocrisy makes us tick.

\section{MAN AND MORALS}

D. J. B. HAWKINS

$10 / 6$ net

The possibility of morals without religion is a question that has been hotly debated for some time, not the least on the B.B.C. Canon Hawkins examines the rational implications of morality in this book and considers the implications of the natural law.

\section{AN INTRODUCTION TO WESTERN PHILOSOPHY}

\section{RUSSELL COLEBURT \\ $1 S /-n e t$}

An examination of the questions about existence which Western man first asked himself and continued to ask through the centuries. 


\title{
An Introduction to Peirce's Philosophy
}

\author{
by JAMES FEIBLEMAN
}

An attempt to organize the main outlines of Peirce's thoughts and to present them systematically for the convenience of those who wish to become acquainted with the depth and range of the first and greatest of American philosophers.

sos.

\section{The Integral Philosophy of Sri Aurobindo}

\section{Edited by HARIDAS CHAUDURI and FREDERIC SPEIGELBERG}

A symposium consisting of articles contributed by thirty eminent scholars who have discussed different aspects-philosophical, psychological, ethicoreligious, political, etc. - of Sri Aurobindo's contribution to civilization.

425.

\section{The Brahma Sutra}

\author{
by Dr. SIR S. RADHAKRISHNAN
}

A study of one of the spiritual and historical classics of India. Of the highest erudition and authority, it will prove invaluable to all those who are interested in the problem of man's spiritual quest and fulfilment. $42 s$.

\section{The Paradox of Tragedy}

\section{by D. D. RAPHAEL}

Two essays which discuss the philosophical aspects of tragedy and drama; and show why we enjoy tragic drama even with its themes of death and disaster.

I 6 s.

\section{Human Potentialities}

\section{by GARDNER MURPHY}

An exploration of the future directions of human development.

"A scholarly work but a highly readable and informative one."-John O' Londons 255.

\section{The Human Spirit}

\section{Edited by WHIT BURNETT}

Forty famous people set forth their most intense personal observations and experiences, and reveal in a profoundly personal way what for them are the most significant aspects of living.

255.

\section{ALLEN \& UNWIN}

4० MUSEUM STREET, LONDON, W.C. I 